OPEN ACCESS

Edited by:

Chi Wei Su,

Qingdao University, China

Reviewed by:

Weike Zhang,

Sichuan University, China

Meng Qin,

Central Party School of the

Communist Party of China, China

${ }^{*}$ Correspondence:

Shun-Bin Zhong

2018110169@email.cufe.edu.cn

Specialty section

This article was submitted to

Health Economics,

a section of the journal

Frontiers in Public Health

Received: 19 September 2021

Accepted: 04 October 2021

Published: 23 December 2021

Citation:

Shen W-T, Yu X, Zhong S-B and Ge H-R (2021) Population Health

Effects of Air Pollution: Fresh Evidence

From China Health and Retirement

Longitudinal Survey

Front. Public Health 9:779552.

doi: 10.3389/fpubh.2021.779552

\section{Population Health Effects of Air Pollution: Fresh Evidence From China Health and Retirement Longitudinal Survey}

\author{
Wei-Teng Shen ${ }^{1}$, Xuan $\mathrm{Yu}^{2}$, Shun-Bin Zhong ${ }^{3 *}$ and Hao-Ran $\mathrm{Ge}^{1}$ \\ ${ }^{1}$ Business School, Zhejiang Wanli University, Ningbo, China, ${ }^{2}$ Business School, Ningbo University, Ningbo, China, ${ }^{3}$ School of \\ Information, Central University of Finance and Economics, Beijing, China
}

The effects of air pollution on population health are currently a hot topic. However, few studies have examined the physical and mental health effects of air pollution jointly in China. Using data from the China Health and Retirement Longitudinal Study (CHARLS) in 2015 and 2018, this study explores how air pollution affects the physical and mental health of middle-aged and elderly residents. The empirical results highlight that air pollution can negatively affect both physical and mental health. In terms of physical health, those exposed to chronic shock are likely to suffer more adverse effects from air pollution than those exposed to acute shock. In terms of mental health, those exposed to depression suffer greater adverse effects than those exposed to episodic memory and mental cognition. Besides, heterogeneity analysis also shows that air pollution affects the mental and physical health of males more than females. Furthermore, the increase in air pollution is expected to result in huge hospitalization costs. Therefore, the Chinese government should formulate differentiated public health policies to reduce the effects of air pollution on the health of middle-aged and elderly residents.

Keywords: air pollution, population health, physical health, mental health, hospitalization costs

\section{INTRODUCTION}

This paper aims to explore whether air pollution impacts the health of China's middle-aged and elderly population, and how it affects their physical and mental health during the period of 20152018. Around the world, air pollution is widely recognized as a health hazard. According to the Global Burden of Disease Report 2019 (1), air pollution has caused 6.67 million deaths worldwide in 2019. As one of newly industrialized countries, China has experienced significant air pollution due to its rapid and extensive economic growth (2). As a response to increasing air pollution, the Chinese government has issued an Air Pollution Prevention and Control Action Plan in 2013. This plan includes strict monitoring of the heavy pollution sector. There have been some effects of the policy, but the situation is less than optimistic. According to the Bulletin of State of China's Ecological Environment in 2020 (3), the air quality in $40.1 \%$ of all cities at the prefecture-level and above is below the required standard. Air pollution is closely related to mortality rate (4-6). In particular, the outbreaks of infectious diseases, such as the coronavirus disease 2019 (COVID-19) can exacerbate the health effects of air pollution (7). In most parts of China, air pollution-related disabilities and deaths has exceeded $20 \%$, and Beijing and its surrounding areas have reached about 
$40 \%$ (1). According to estimates by Geng et al. (8), the number of PM2.5-related deaths increased by 390,000 from 2002 to 2017, and the usage of emission control technologies for end-ofpollution prevented 870,000 deaths from air pollution.

A research hotspot has emerged around air pollution's effect on population health. Short-term exposure to air pollution may cause chronic obstructive pulmonary disease, coughing, shortness of breath, wheezing, asthma, and respiratory diseases, while long-term exposure to air pollution may cause chronic asthma, pulmonary insufficiency, cardiovascular disease, and cardiovascular death (9). There has been extensive research on whether air pollution causes the various diseases mentioned above. Particulate pollution, such as PM2.5, can damage people's lungs through their blood circulation $(10,11)$, increasing the risk of respiratory infections and lung cancer $(4,12)$. The inhalation of fine particles can result in hypercoagulability, platelet sensitization, systemic inflammation and oxidative stress. It directly or indirectly causes vascular damage, atherosclerosis and autonomic dysfunction, which could lead to cardiovascular disease (13-15). Moreover, the effects of air pollution on population health are not uniform across all groups. Children and the elderly are especially vulnerable to the adverse effects of air pollution (16-19). As a result, there have been many studies specifically focused on the effects of air pollution on the health of children (20-22) and the elderly $(23,24)$.

In the above research, the effects of air pollution on physical health are mainly discussed. However, air pollution can also affect mental health. For example, increasing PM2.5 concentrations can lead to negative emotional responses such as depression, nervousness, restlessness, and irritability (25-27). Two mechanisms are at work in causing the adverse effects of air pollution on mental health. On the one hand, inhaling air pollutants from the atmosphere, especially PM2.5, can cause oxidative stress and inflammatory conditions in the human body $(28,29)$. On the other hand, a lack of green is widely believed to be associated with mental health problems, such as depression and anxiety $(30,31)$, as well as cognitive impairment (32). To explain these findings, several theories have been proposed, including limitations on physical activity, biodiversity hypotheses, biogenesis theories and social stressors (33).

In summary, this study may make three marginal contributions to the literature. First of all, this study provides fresh microscopic evidence on population health effects of air pollution using data from the China Health and Retirement Longitudinal Study (CHARLS) in 2015 and 2018. CHARLS is a survey that specifically targets the health issues of middle-aged and elderly people. Comparatively with other studies that use large-scale micro-surveys to explore the health of middle-aged and elderly people $(34,35)$, the sample selected by CHARLS is more representative and the questionnaire design is more targeted. In addition, previous CHARLS health research mainly used cross-sectional data from a particular year $(36,37)$, while this study used panel data including 2015 and 2018. This allows us to control factors that do not change over time, which help us estimate how air pollution impacts health accurately.

Secondly, this study evaluates both the physical and mental health effects of air pollution. Most existing literature currently studies either the physical health or the mental health effect of air pollution without simultaneously exploring both. We find that air pollution can adversely affect physical and mental health. 10 increase of AQI will experience 0.72 increase of physical health index. An increase of $0.72 \%$ is economically significant considering average physical health index are only -0.053 . The index of mental health decreases about 0.15 for every 1 increase of AQI which is equal to $23.70 \%$ of the sample mean.

Thirdly, this study enriches the measurement of physical health and mental health, and as well as analyzes the heterogeneity from different perspectives of health and gender. For physical health, existing research mainly focuses on the effect of air pollution on cardiovascular diseases or respiratory conditions. However, air pollution may also affect liver diseases, diabetes, stomach diseases, hypertension and so on. For mental health, existing research mainly concentrates on specify factors, such as depression and cognition, and cannot fully capture the effect that air pollution has on mental health. Therefore, this study constructs a comprehensive index of physical health and mental health, respectively. We find that for every one standard deviation increase in AQI, the acute shock and chronic shock will increase by 0.191 and 2.162 standard deviations, respectively. Accordingly, the episodic memory will decrease by 0.605 standard deviations, mental cognition by 0.852 , and self-reported will increase by 1.032 standard deviations.

The rest of this study is organized as follows: section "Theoretical Analysis" presents the impact mechanism of air pollution on health. Section "Data and Methodology" describes data source, variables selection and methodology. The empirical results are presented and discussed in the section "Empirical Results". Section "Conclusions and implications" concludes the paper.

\section{THEORETICAL ANALYSIS}

Air pollution can affect health in many ways. It can have a negative effect on physical health. Firstly, air pollution can directly cause damage to human cells, tissues and organs. Air pollutants can directly lead to the disruption of the airway epithelial barrier and cell signaling pathways (38), injury from free radical peroxidation (39), imbalanced intracellular calcium homeostasis (39), Inflammatory injury (40), cellular immune disorders (41), epigenetic modification (42), and autophagy (43), thereby causing chronic respiratory diseases (39, 44). Air pollution can also cause cardiovascular disease. Pollutants can cause epigenetic changes with downstream effects on the cardiovascular system. They also activate inflammatory cells in the lungs, including macrophages, leading to increased systemic inflammation and oxidative stress, thereby cardiac dysfunction (45). In addition, exposure to pollution can cause sleep quality decline or insomnia caused by shortness of breath, increased heart rate, upper respiratory tract irritation, thereby cause other diseases (46). Secondly, aerosol particles can scatter and absorb surface solar radiation directly. As cloud condensation nuclei, aerosols can indirectly affect the solar radiation on the ground by changing the number of cloudiness $(47,48)$. The lack of sunlight 
will not be conducive to the formation of vitamin $\mathrm{D}$, thereby increasing the risk of chronic diseases and cancer (49). Thirdly, people might reduce outdoor activity time during a severe air pollution episode (50), thereby insufficient exercise. Lack of exercise may lead to health problems such as reduced human organ function, slowed blood circulation, slowed metabolism, weakened immunity, and other health problems. Finally, air pollution will increase the probability of workers getting sick, reduce working hours, work efficiency (51), thereby a decline in workers' income.

Air pollution can also adversely affect people's mental health. First of all, the fine particles that cause air pollution may increase the body's oxidative stress and systemic inflammation. These changes can severely destroy the cytokine signals that regulate brain function, manifested as depression (52), anxiety (53) and cognitive dysfunction $(54,55)$. In addition, air pollution can induce a variety of physical health diseases, such as cardiovascular, respiratory, and obstructive lung diseases. The patients who are suffering from illness will have a negative psychological status. This is harmful to mental health and may even increase the risk of suicide (56). Finally, to reduce the potential risk of exposure to air pollution, people may increase the time spent indoors. Staying indoors for a long time can increase people's feelings of anxiety and loneliness which is harmful to mental health (57). Air pollution can also have an indirect impact on mental health. Air pollution may cause macroeconomic fluctuations by reducing enterprise performance and hindering foreign direct investment (58). The deterioration of the macro economy will cause workers to worry about future job loss and income reduction, which will adversely affect mental health (59).

\section{DATA AND METHODOLOGY}

\section{Data Source}

The dataset of individual characteristic variables has been collected from the China Health and Retirement Longitudinal Study (CHARLS) in 2015 and 2018. So far, CHARLS has conducted the first, second, third, and fourth rounds of investigations in 2011, 2013, 2015, and 2018, respectively. The reason why we excluded 2011 and 2013 from the analysis is the items on the mental health part of the questionnaires in 2011 and 2013 are incomplete, and the questionnaires in 2015 and 2018 are more complete and unify than 2011 and 2013. The CHARLS is organized and carried out by the National Development Research Institute of Peking University, and it is a biannual and nationally representative survey of middle-aged and elderly population aged 45 and above. The CHARLS national baseline was carried out in 2011 and then tracked every 2-3 years. The data covers approximately 17,708 residents in 150 county-level units and 450 village-level units in China. Detailed descriptions of individual sampling methods are provided in the user manual compiled by Zhao et al. (60). There is a wide range of information provided in CHARLS, including health status and function, health care and insurance, cognition and depression, and other individual basic information. Therefore, CHARLS is a representative data to study population health and its influencing factors among middle-aged and elderly people.

\section{Variable Selection Dependent Variable}

The dependent variable is population health, which is measured from two dimensions: physical health and mental health. In terms of physical health, it can be measured by acute and chronic shock according to the disease characteristics. In terms of mental health, it is evaluated by three aspects: episodic memory, mental cognition and self-reported depression. Due to the fact that different indicators have different dimensions, this study standardizes the secondary indicators and then carries out a simple arithmetic average method to obtain the sum of physical health and mental health, respectively. Specially, Table 1 presents the constructed indicators for measuring physical health and mental health.

\section{Independent Variable}

The core independent variable of this study is the air pollution. According to the current literature on air pollution in China, the main measurement indicators of air pollution are the air quality index (AQI), the air pollution index (API), PM2.5, SO2, CO, NO2 and $\mathrm{O} 3$ (4, 20, 46, 61-63). Among them, AQI has recently been widely accepted as the most reliable and representative indicator for measuring air pollution. AQI is calculated as a composite indicator of PM2.5, PM10, SO2, $\mathrm{CO}, \mathrm{NO} 2$, and $\mathrm{O} 3$, ranging from 0 to 500 . The higher the AQI, the worse the air pollution. Hence, this study collects the daily AQI of prefecture-level cities in 2015 and 2018 from the China National Environmental Monitoring Center, and then calculates the annual average of AQI of each city in 2015 and 2018. In addition, this study also uses two common single indicators of PM2.5 and PM10 respectively in the robustness check.

\section{Control Variable}

The control variables include individual-level and city-level variables. Refer to previous related studies of $\mathrm{Gu}$ et al. (64), Hu et al. (65), and Giaccherini et al. (66), this study controls for the individual characteristics including education level, age, gender, marital status, sleep status, whether they have medical insurance, and whether they are accompanied by children. Meanwhile, this study also controls for the urban characteristics including waste treatment rate, sewage treatment rate, population density, medical level, and economic development level.

\section{Variable Description}

Table 2 shows the definition and descriptive statistics of each variable in this study. As Table 2 shows, the values of physical and mental health range from-1.005 to 5.205 and-4.680 to 4.262 , respectively, indicating that the health status varies greatly among individuals. The average value of AQI is 76.590, suggesting that air pollution in China is severe in 2015 and 2018. In terms of individual characteristics, the average values of education level and gender are 6.650 and 0.480 , which means that the sample data used in this study has good representativeness. In terms of urban characteristics, the average centralized sewage treatment 
TABLE 1 | Indicators for measuring physical and mental health.

\begin{tabular}{|c|c|c|c|c|c|c|c|c|}
\hline \multicolumn{2}{|c|}{ Primary indicators } & Secondary indicators & \multicolumn{2}{|l|}{ Definition of indicator } & \multicolumn{4}{|c|}{ Indicator attribute } \\
\hline \multirow{2}{*}{\multicolumn{2}{|c|}{ Physical health }} & Acute shock & \multicolumn{2}{|c|}{$\begin{array}{l}\text { One point is scored for each of the three diseases of stroke, heart } \\
\text { disease, and cancer. The range of values is }[0,3] \text {. }\end{array}$} & \multicolumn{4}{|c|}{$\begin{array}{l}\text { The higher value of this indicator, the stronger } \\
\text { of acute shock and the worser of physical } \\
\text { health. }\end{array}$} \\
\hline & & Chronic shock & \multicolumn{2}{|c|}{$\begin{array}{l}\text { One point is scored for each of hypertension, diabetes, kidney, } \\
\text { chronic lung, asthma, dyslipidemia, liver disease, stomach } \\
\text { disease, and arthritis. The range of values is }[0,9] .\end{array}$} & \multicolumn{4}{|c|}{$\begin{array}{l}\text { The higher value of this indicator, the stronger } \\
\text { of chronic shock and the worser of physical } \\
\text { health. }\end{array}$} \\
\hline \multirow{3}{*}{\multicolumn{2}{|c|}{ Mental health }} & Episodic memory & \multicolumn{2}{|c|}{$\begin{array}{l}\text { The memory includes short-term memory and delayed memory. } \\
\text { There are } 20 \text { questions to answer, and each correct answer is } \\
\text { worth one point. The range of values is }[0,20] \text {. }\end{array}$} & \multicolumn{4}{|c|}{$\begin{array}{l}\text { The higher value of this indicator, the stronger } \\
\text { of the ability of episodic memory and the } \\
\text { healthier of mental health. }\end{array}$} \\
\hline & & Mental cognition & \multicolumn{2}{|c|}{$\begin{array}{l}\text { Answer questions about dates, seasons, drawings, calculations, } \\
\text { etc., and mark one point for each correct answer. The range of } \\
\text { values is }[0,12] .\end{array}$} & \multicolumn{4}{|c|}{$\begin{array}{l}\text { The higher value of this indicator, the stronger } \\
\text { of the ability of mental cognition and the } \\
\text { healthier of mental health. }\end{array}$} \\
\hline & & Self-reported depression & \multicolumn{2}{|c|}{$\begin{array}{l}\text { It contains } 10 \text { questions about feelings and behaviors in the last } \\
\text { week. Respondents choose from four options that indicate the } \\
\text { frequency and add the representative scores of the options to } \\
\text { obtain a self-reported depression score. The range of values is } \\
{[0,40] \text {. }}\end{array}$} & \multicolumn{4}{|c|}{$\begin{array}{l}\text { The higher value of this indicator, the higher of } \\
\text { the self-reported depression and the worse of } \\
\text { mental health. }\end{array}$} \\
\hline Variable & \multicolumn{2}{|c|}{ Definition } & & Obs & Mean & SD & Min & Max \\
\hline Phyheal & \multicolumn{3}{|c|}{ The higher the value of Phyheal, the worse the physical health } & 39,492 & -0.053 & 1.117 & -1.005 & 5.205 \\
\hline Menheal & \multicolumn{3}{|c|}{ The higher the value of Menheal, the better the mental health } & 17,250 & 0.638 & 1.990 & -4.680 & 4.262 \\
\hline AQI & \multicolumn{3}{|c|}{ AQI index (The larger the value, the more serious the air pollution) } & 36,129 & 76.590 & 22.211 & 33.971 & 138.504 \\
\hline Education & \multicolumn{3}{|c|}{ Education level (The higher the value, the higher the level of education) } & 39,634 & 6.650 & 4.439 & 1.000 & 12.000 \\
\hline Age & \multicolumn{3}{|c|}{ Age of the resident } & 38,712 & 61.105 & 10.079 & 45.000 & 87.000 \\
\hline Gender & \multicolumn{3}{|c|}{$1=$ male, $0=$ female } & 39,650 & 0.480 & 0.500 & 0.000 & 1.000 \\
\hline Married & \multicolumn{3}{|c|}{ Married $=1$, unmarried $=0$} & 39,617 & 0.857 & 0.350 & 0.000 & 1.000 \\
\hline Lwchi & \multicolumn{3}{|c|}{ Accompanied by children, $1=$ yes, $0=$ no } & 20,979 & 0.405 & 0.491 & 0.000 & 1.000 \\
\hline Sleep & \multicolumn{3}{|c|}{ Sleep quality (The larger the value, the worse the sleep quality) } & 36,239 & 2.080 & 1.217 & 1.000 & 4.000 \\
\hline Medins & \multicolumn{3}{|c|}{ Whether the respondent enrollment in social basic medical insurance, $1=$ yes, $0=$ no } & 19,540 & 0.970 & 0.171 & 0.000 & 1.000 \\
\hline sewpro & \multicolumn{3}{|c|}{ Centralized sewage treatment rate (\%) } & 33,455 & 90.903 & 6.994 & 64.430 & 100.000 \\
\hline gartre & \multicolumn{3}{|c|}{ Harmless garbage disposal rate (\%) } & 34,067 & 95.729 & 9.654 & 40.700 & 100.000 \\
\hline bedper & \multicolumn{3}{|c|}{ Number of hospital beds per 10,000 people } & 35,677 & 47.010 & 16.879 & 21.895 & 98.333 \\
\hline Indensity & \multicolumn{3}{|c|}{ Logarithm of population density } & 35,756 & 5.933 & 0.905 & 2.281 & 7.113 \\
\hline Inpergdp & \multicolumn{3}{|c|}{ Logarithm of GDP per capita } & 35,756 & 10.703 & 0.652 & 9.382 & 12.431 \\
\hline
\end{tabular}

and harmless garbage disposal rates reach $90.903 \%$ and $95.729 \%$ respectively. It implies that the impacts of environmental pollution on population health may also an important factor in the sample data.

\section{Methodology}

According to Grossman's health demand theory (67), the health capital stock could be influenced by age, income, environmental pollution level, lifestyle, education, and other factors. Based on the health demand theory and the settings of Chen et al. (20), Liao et al. (4), Heyes and Zhu (46), we constructed the following model:

$$
\begin{array}{r}
\text { Health }_{\text {ict }=} \alpha_{0}+\alpha_{1} \text { Airpollution }_{\text {ict }}+\sum_{v=2}^{12} \alpha_{v} \text { Contronl }_{v}+\gamma_{c}+\lambda_{t} \\
+\varepsilon_{i c t}
\end{array}
$$

where Health $h_{i c t}$ is the health level of individual $i$ living in city $c$ in year $t$. In this study, health is further divided into physical health and mental health, respectively. Airpollution ict $_{\text {is }}$ the air pollution level of individual $i$ living in city $c$ in year $t$. Contronl $l_{v}$ represents the control variables, including individual and urban characteristics. $\gamma_{c}$ is the city fixed effects. $\lambda_{t}$ is the year fixed effects. The city and year fixed effects are introduced to control the unobservable factors changing with city and time. $\varepsilon_{i c t}$ is the error term. $\alpha_{0}, \alpha_{1}, \ldots \alpha_{12}$ are the parameters to be estimated.

\section{EMPIRICAL RESULTS}

\section{Baseline Regression Results}

The results of the baseline regression are reported in Table 3. Columns (1) and (2) show the estimated results of air pollution on residents' physical health and mental health, respectively. As 
TABLE 3 | The effects of air pollution on physical and mental health.

\begin{tabular}{|c|c|c|}
\hline & $\begin{array}{c}\text { (1) } \\
\text { Phyheal }\end{array}$ & $\begin{array}{c}\text { (2) } \\
\text { Menheal }\end{array}$ \\
\hline AQI & $\begin{array}{l}0.0723^{\star \star \star} \\
(0.0019)\end{array}$ & $\begin{array}{c}-0.1512^{\star * \star} \\
(0.0029)\end{array}$ \\
\hline Education & $\begin{array}{c}0.0022 \\
(0.0101)\end{array}$ & $\begin{array}{c}0.4595^{\star \star \star} \\
(0.0160)\end{array}$ \\
\hline Age & $\begin{array}{l}0.0123^{\star \star \star} \\
(0.0019)\end{array}$ & $\begin{array}{c}-0.0329^{\star \star \star} \\
(0.0030)\end{array}$ \\
\hline Gender & $\begin{array}{r}0.0110 \\
(0.0443)\end{array}$ & $\begin{array}{c}0.0325 \\
(0.0494)\end{array}$ \\
\hline Married & $\begin{array}{r}0.0046 \\
(0.0370)\end{array}$ & $\begin{array}{c}0.4249^{\star \star \star} \\
(0.0592)\end{array}$ \\
\hline Lwchi & $\begin{array}{l}-0.0190 \\
(0.0280)\end{array}$ & $\begin{array}{c}0.0407 \\
(0.0396)\end{array}$ \\
\hline Sleep & $\begin{array}{c}0.1293^{\star \star \star} \\
(0.0158)\end{array}$ & $\begin{array}{c}-0.5193^{\star \star \star} \\
(0.0240)\end{array}$ \\
\hline Medins & $\begin{array}{l}0.2109^{\star \star \star} \\
(0.0712)\end{array}$ & $\begin{array}{l}0.5155^{\star \star} \\
(0.1906)\end{array}$ \\
\hline sewpro & $\begin{array}{l}-0.0349^{\star \star \star} \\
(0.0017)\end{array}$ & $\begin{array}{c}0.1139^{\star \star \star} \\
(0.0021)\end{array}$ \\
\hline gartre & $\begin{array}{l}0.0841^{* \star *} \\
(0.0020)\end{array}$ & $\begin{array}{c}-0.1610^{\star * \star} \\
(0.0035)\end{array}$ \\
\hline bedper & $\begin{array}{l}0.0033^{\star \star \star} \\
(0.0001)\end{array}$ & $\begin{array}{c}-0.0165^{\star \star \star} \\
(0.0004)\end{array}$ \\
\hline Indensity & $\begin{array}{l}0.2754^{\star \star \star} \\
(0.0117)\end{array}$ & $\begin{array}{c}0.0801^{\star \star \star} \\
(0.0135)\end{array}$ \\
\hline Inpergdp & $\begin{array}{l}0.2481^{\star \star \star} \\
(0.0115)\end{array}$ & $\begin{array}{c}-0.4676^{\star \star \star} \\
(0.0225)\end{array}$ \\
\hline City fixed effects & Yes & Yes \\
\hline Year fixed effects & Yes & Yes \\
\hline Constant & $\begin{array}{c}-15.9956^{\star \star \star} \\
(0.3278)\end{array}$ & $\begin{array}{c}22.2470^{\star \star \star} \\
(0.5363)\end{array}$ \\
\hline Observations & 7624 & 6098 \\
\hline Adjusted $R^{2}$ & 0.038 & 0.444 \\
\hline
\end{tabular}

Standard errors in parentheses, clustered at the Provincial level. * ${ }^{* *}$, and ${ }^{* \star *}$ indicate significance at the levels of 10,5 , and $1 \%$, respectively.

shown in column (1), the coefficient of AQI is positive and significant at the $1 \%$ level, implying that increasing air pollution will be detrimental to physical health. The estimated coefficient value of AQI is 0.0723 , suggesting that every 10 units increase of AQI will experience 0.72 increase of index of physical health. It's worth noting that an increase of 0.72 is also economically significant considering average physical health index are only -0.053 . In addition, as shown in column (2), the coefficient of AQI is negative and significant at the $1 \%$ level, indicating that increasing air pollution is also harmful to mental health. Specifically, the estimated coefficient -0.1512 means that the index of mental health decreases about 0.15 for every 1 increase of AQI. This is equal to $23.70 \%$ of the sample mean, suggesting that air pollution contributes a large negative effect to residents' mental health. Existing studies have found that air pollution can increase the risk of diseases such as dementia (68), asthma (69), depression (26), and lung cancer (10). The results of these studies provide some support for the above findings.
TABLE 4 | Results after changing the measurement of the dependent variable.

\begin{tabular}{|c|c|c|}
\hline & $\begin{array}{c}\text { (1) } \\
\text { Hosptime }\end{array}$ & $\begin{array}{c}\text { (2) } \\
\text { Menheal2 }\end{array}$ \\
\hline AQI & $\begin{array}{l}0.0492^{\star \star \star} \\
(0.0009)\end{array}$ & $\begin{array}{c}0.0099^{\star \star \star} \\
(0.0003)\end{array}$ \\
\hline Education & $\begin{array}{c}0.0004 \\
(0.0043)\end{array}$ & $\begin{array}{c}0.0015 \\
(0.0012)\end{array}$ \\
\hline Age & $\begin{array}{l}0.0107^{\star \star \star} \\
(0.0008)\end{array}$ & $\begin{array}{c}0.0002 \\
(0.0003)\end{array}$ \\
\hline Gender & $\begin{array}{c}0.0231 \\
(0.0148)\end{array}$ & $\begin{array}{c}-0.0126^{\star \star} \\
(0.0055)\end{array}$ \\
\hline Married & $\begin{array}{l}-0.0125 \\
(0.0268)\end{array}$ & $\begin{array}{c}-0.0159^{*} \\
(0.0091)\end{array}$ \\
\hline Lwchi & $\begin{array}{c}0.0021 \\
(0.0122)\end{array}$ & $\begin{array}{l}-0.0072 \\
(0.0080)\end{array}$ \\
\hline Sleep & $\begin{array}{l}0.0423^{\star \star \star} \\
(0.0039)\end{array}$ & $\begin{array}{c}0.0164^{\star \star \star} \\
(0.0018)\end{array}$ \\
\hline Medins & $\begin{array}{l}0.1513^{\star \star \star} \\
(0.0317)\end{array}$ & $\begin{array}{l}-0.0069 \\
(0.0225)\end{array}$ \\
\hline sewpro & $\begin{array}{c}-0.0390^{\star \star \star} \\
(0.0009)\end{array}$ & $\begin{array}{c}-0.0052^{\star \star \star} \\
(0.0003)\end{array}$ \\
\hline gartre & $\begin{array}{l}0.0665^{\star \star \star} \\
(0.0011)\end{array}$ & $\begin{array}{c}0.0119^{\star \star \star} \\
(0.0004)\end{array}$ \\
\hline bedper & $\begin{array}{l}0.0048^{\star \star \star} \\
(0.0001)\end{array}$ & $\begin{array}{c}-0.0010^{\star \star \star} \\
(0.0000)\end{array}$ \\
\hline Indensity & $\begin{array}{l}0.0643^{\star \star \star} \\
(0.0055)\end{array}$ & $\begin{array}{c}-0.0066^{\star \star \star} \\
(0.0023)\end{array}$ \\
\hline Inpergdp & $\begin{array}{c}0.1886^{\star \star \star} \\
(0.0058)\end{array}$ & $\begin{array}{c}0.1119^{\star \star \star} \\
(0.0021)\end{array}$ \\
\hline City fixed effects & Yes & Yes \\
\hline Year fixed effects & Yes & Yes \\
\hline Constant & $\begin{array}{l}-9.6388^{\star \star \star} \\
(0.1511)\end{array}$ & $\begin{array}{c}-2.5107^{\star \star \star} \\
(0.0454)\end{array}$ \\
\hline Observations & 7628 & 7624 \\
\hline Adjusted $R^{2}$ & 0.053 & 0.012 \\
\hline
\end{tabular}

Standard errors in parentheses, clustered at the Provincial level. * ${ }^{* *}$, and ${ }^{* * *}$ indicate significance at the levels of 10,5 , and $1 \%$, respectively.

\section{Robustness Checks}

\section{Using Other Dependent Variables}

Although multiple options are integrated to construct population health, some key health issues may still be overlooked. For robustness checks, we use the numbers of hospitalization to measure physical health. Here we actually assume that the more hospitalizations, the worse the physical health. As shown in column (1) of Table 4, the regression coefficient of AQI is positive and significant at the $1 \%$ level. The estimated results indicate that increasing air pollution will result in more hospitalizations, and more hospitalizations reflect poorer physical health. As a consequence, the conclusion in the baseline that air pollution is bad for population health still remains valid.

In the CHARLS questionnaire, there is a question entitled, "Are you currently using these methods to treat mental, psychological, or emotional disorders?" This question is for respondents with a mental, psychological, or emotional illness. The options for this question include " 1 . Receiving psychiatric 
TABLE 5 | Results of PM2.5 and PM10 as the independent variables.

\begin{tabular}{|c|c|c|c|c|}
\hline & $\begin{array}{c}\text { (1) } \\
\text { Phyheal }\end{array}$ & $\begin{array}{c}\text { (2) } \\
\text { Menheal }\end{array}$ & $\begin{array}{c}\text { (3) } \\
\text { Phyheal }\end{array}$ & $\begin{array}{c}\text { (4) } \\
\text { Menheal }\end{array}$ \\
\hline PM2.5 & $\begin{array}{l}0.0730^{\star \star \star} \\
(0.0019)\end{array}$ & $\begin{array}{c}-0.1527^{\star \star \star} \\
(0.0029)\end{array}$ & & \\
\hline PM10 & & & $\begin{array}{l}0.1259^{* \star \star} \\
(0.0033)\end{array}$ & $\begin{array}{c}-0.2634^{\star \star \star} \\
(0.0050)\end{array}$ \\
\hline Education & $\begin{array}{r}0.0022 \\
(0.0101)\end{array}$ & $\begin{array}{c}0.4595^{\star \star \star} \\
(0.0160)\end{array}$ & $\begin{array}{c}0.0022 \\
(0.0101)\end{array}$ & $\begin{array}{c}0.4595^{\star \star \star} \\
(0.0160)\end{array}$ \\
\hline Age & $\begin{array}{l}0.0123^{\star \star \star} \\
(0.0019)\end{array}$ & $\begin{array}{c}-0.0329^{\star \star \star} \\
(0.0030)\end{array}$ & $\begin{array}{l}0.0123^{\star \star \star} \\
(0.0019)\end{array}$ & $\begin{array}{c}-0.0329^{\star \star \star} \\
(0.0030)\end{array}$ \\
\hline Gender & $\begin{array}{r}0.0110 \\
(0.0443)\end{array}$ & $\begin{array}{c}0.0325 \\
(0.0494)\end{array}$ & $\begin{array}{r}0.0110 \\
(0.0443)\end{array}$ & $\begin{array}{c}0.0325 \\
(0.0494)\end{array}$ \\
\hline Married & $\begin{array}{r}0.0046 \\
(0.0370)\end{array}$ & $\begin{array}{c}0.4249^{\star \star \star} \\
(0.0592)\end{array}$ & $\begin{array}{r}0.0046 \\
(0.0370)\end{array}$ & $\begin{array}{c}0.4249^{\star \star \star} \\
(0.0592)\end{array}$ \\
\hline Lwchi & $\begin{array}{l}-0.0190 \\
(0.0280)\end{array}$ & $\begin{array}{c}0.0407 \\
(0.0396)\end{array}$ & $\begin{array}{l}-0.0190 \\
(0.0280)\end{array}$ & $\begin{array}{c}0.0407 \\
(0.0396)\end{array}$ \\
\hline Sleep & $\begin{array}{l}0.1293^{\star \star \star} \\
(0.0158)\end{array}$ & $\begin{array}{c}-0.5193^{\star \star \star} \\
(0.0240)\end{array}$ & $\begin{array}{c}0.1293^{\star \star \star} \\
(0.0158)\end{array}$ & $\begin{array}{c}-0.5193^{\star \star \star} \\
(0.0240)\end{array}$ \\
\hline Medins & $\begin{array}{l}0.2109^{\star \star \star} \\
(0.0712)\end{array}$ & $\begin{array}{l}0.5155^{\star \star} \\
(0.1906)\end{array}$ & $\begin{array}{l}0.2109^{\star \star \star} \\
(0.0712)\end{array}$ & $\begin{array}{l}0.5155^{\star \star} \\
(0.1906)\end{array}$ \\
\hline sewpro & $\begin{array}{c}-0.0104^{\star \star \star} \\
(0.0011)\end{array}$ & $\begin{array}{c}0.0626^{\star \star \star} \\
(0.0014)\end{array}$ & $\begin{array}{c}-0.1505^{\star \star \star} \\
(0.0046)\end{array}$ & $\begin{array}{c}0.3557^{* \star \star} \\
(0.0065)\end{array}$ \\
\hline gartre & $\begin{array}{l}0.0681^{\star * *} \\
(0.0017)\end{array}$ & $\begin{array}{c}-0.1275^{\star \star \star} \\
(0.0029)\end{array}$ & $\begin{array}{l}0.1984^{\star \star \star} \\
(0.0050)\end{array}$ & $\begin{array}{c}-0.4001^{\star \star \star} \\
(0.0080)\end{array}$ \\
\hline bedper & $\begin{array}{c}-0.0173^{\star \star \star} \\
(0.0005)\end{array}$ & $\begin{array}{c}0.0267^{\star \star \star} \\
(0.0011)\end{array}$ & $\begin{array}{l}0.0514^{\text {** }} \\
(0.0013)\end{array}$ & $\begin{array}{c}-0.1171^{\star \star \star} \\
(0.0018)\end{array}$ \\
\hline Indensity & $\begin{array}{l}0.1477^{\star \star \star} \\
(0.0111)\end{array}$ & $\begin{array}{c}0.3471^{\star \star \star} \\
(0.0159)\end{array}$ & $\begin{array}{l}0.9225^{\star \star \star} \\
(0.0236)\end{array}$ & $\begin{array}{c}-1.2736^{\star \star \star} \\
(0.0249)\end{array}$ \\
\hline Inpergdp & $\begin{array}{l}0.5064^{\star \star \star} \\
(0.0181)\end{array}$ & $\begin{array}{c}-1.0078^{\star \star \star} \\
(0.0326)\end{array}$ & $\begin{array}{l}0.2144^{\star \star \star} \\
(0.0107)\end{array}$ & $\begin{array}{c}-0.3971^{\star \star \star} \\
(0.0212)\end{array}$ \\
\hline City fixed effects & Yes & Yes & Yes & Yes \\
\hline Year fixed effects & Yes & Yes & Yes & Yes \\
\hline Constant & $\begin{array}{c}-15.7287^{\star \star \star} \\
(0.3217)\end{array}$ & $\begin{array}{c}21.6888^{\star \star \star *} \\
(0.5266)\end{array}$ & $\begin{array}{c}-27.4986^{\star \star \star} \\
(0.6085)\end{array}$ & $\begin{array}{c}46.3083^{\star \star \star} \\
(0.9733)\end{array}$ \\
\hline Observations & 7624 & 6098 & 7624 & 6098 \\
\hline Adjusted $R^{2}$ & 0.038 & 0.444 & 0.038 & 0.444 \\
\hline
\end{tabular}

Standard errors in parentheses, clustered at the Provincial level. *, **, and ${ }^{* * *}$ indicate significance at the levels of 10, 5, and 1\%, respectively.

or psychological treatment; 2. Taking anti-depressants; 3 . Taking tranquilizers or sleeping pills; 4 . Other treatments, please specify; 5. None of the above". We set a mental health variable based on the options of the question, and the value is 1 when no corresponding treatment measures are taken, 2 when one of the treatment measures is taken, and so on. The value of this new mental health variable ranges from 1 to 5 . The larger the value, the worse the mental health. In Table 4, column (2) reports the results with new mental health variable as the dependent variable. The results show that the coefficient of AQI is positive and significant at the $1 \%$ level, indicating that increasing air pollution will reduce mental health level. This finding is consistent with the conclusion obtained from Table 3.

\section{Using Other Independent Variables}

As Cheng et al. (70) and Yang et al. (71) have shown, PM2.5 and PM10 are the main pollutants causing air pollution Chinese cities. Hence, we also take them as independent variables for robustness checks. The estimation results are reported in columns (1)-(4) of Table 5. As shown in columns (1) and (3), the regression coefficients of PM2.5 and PM10 are all positive and significant at the $1 \%$ level. The results indicate that an increase in PM2.5 and PM10 concentrations will adversely affect residents' physical health. Meanwhile, the regression coefficients of PM2.5 and PM10 in columns (2) and (4) are all negative and significant at the $1 \%$ level, implying that an increase in PM2.5 and PM10 concentrations will also be detrimental to residents' mental health. These results further verify the reliability of the conclusion that the increase of air pollution will pose a threat to both physical health and mental health.

\section{Heterogeneous Effects of Air Pollution Heterogeneity of Subgroups}

The impact of air pollution on population health may vary among different types of physical health or mental health. Thus, this study investigates the heterogeneous effects of air pollution on 
TABLE 6 | Results of heterogeneity test based on the secondary indicators of physical and mental health.

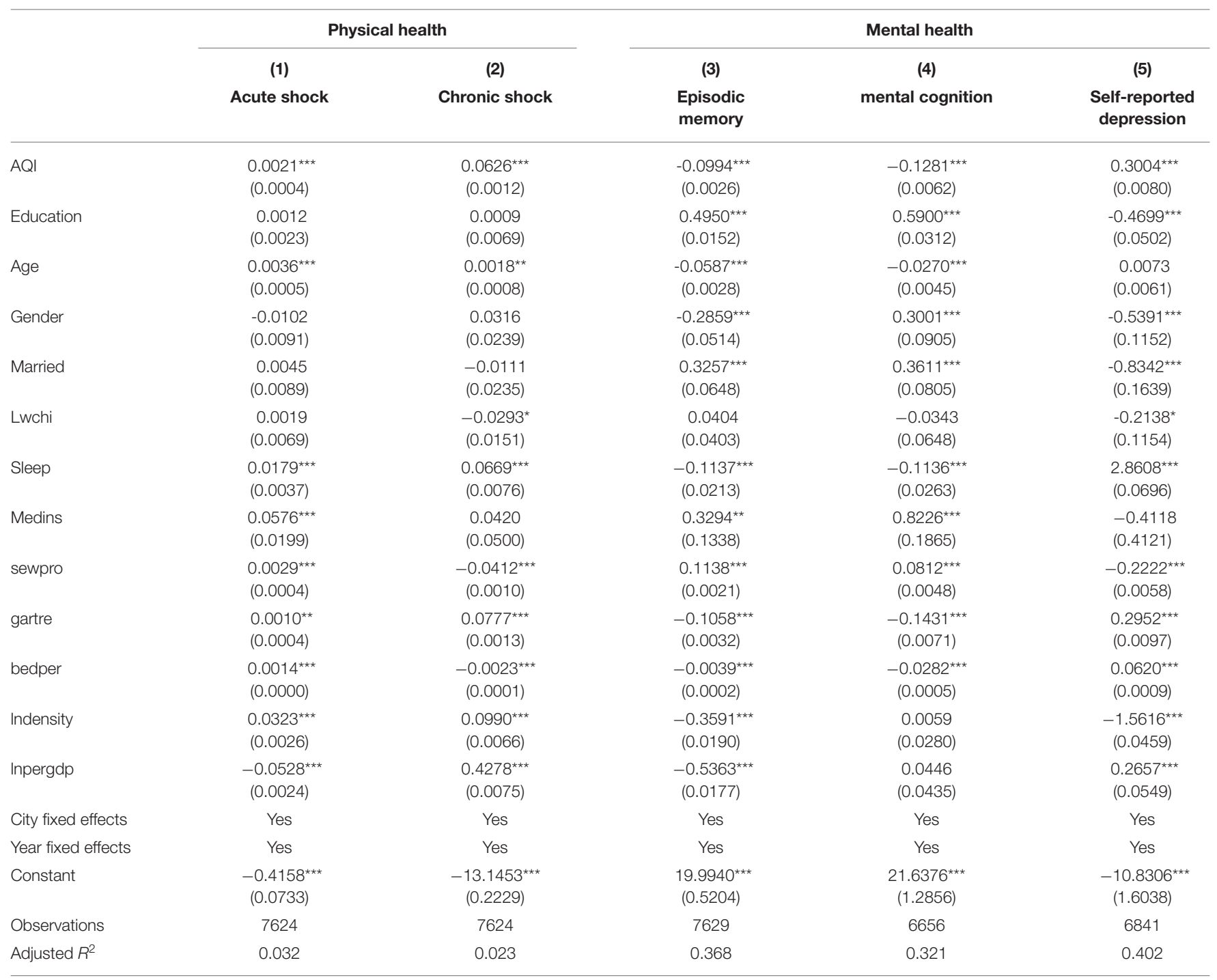

Standard errors in parentheses, clustered at the Provincial level. *, **, and *** indicate significance at the levels of 10, 5, and 1\%, respectively.

physical health based on acute and chronic shocks, and analyzes how air pollution impacts mental health based on episodic memory, mental cognition, and self-reported depression. The estimation results are shown in Table 6.

In terms of physical health, columns (1) and (2) of Table 6 take acute shock and chronic shock as the dependent variables. The coefficients of AQI are both positive and significant at the $1 \%$ level, indicating that air pollution will increase the incidence of acute and chronic diseases, but it is more likely to cause the occurrence of chronic diseases than acute diseases. When taking episodic memory and mental cognition as the dependent variables in columns (3) and (4), the result show that the coefficients of AQI are both negative and significant at the $1 \%$ level. It suggests that Memory and cognitive ability of middle-aged and elderly people will be impaired by air pollution. Moreover, the coefficients of AQI in column (5) is also negative and significant at the $1 \%$ level, indicating that depression will rise among the middle-aged and the elderly due to an increase in air pollution. Therefore, air pollution has a systemic effect on the health of middle-aged and elderly people.

Furthermore, according to Table 2, a standard deviation of $22.211,0.244,0.643,3.652,3.339$, and 6.463 are found in the AQI, acute shock, chronic shock, episodic memory, psychological cognition, and self-reported depression, respectively. Thus, the estimation results in Table 6 can be expressed as for every one standard deviation increase in AQI, the acute shock and chronic shock will increase by 0.191 and 2.162 standard deviations, respectively. Accordingly, the episodic memory will decrease by 0.605 standard deviations, mental cognition by 0.852 , and selfreported depression will increase by 1.032 standard deviations.

\section{Heterogeneity of Gender}

The effects of air pollution on population health may differ among males and females due to differences in physical structures 
TABLE 7 | Results of heterogeneity test based on gender.

\begin{tabular}{|c|c|c|c|c|}
\hline & \multicolumn{2}{|c|}{ Physical health } & \multicolumn{2}{|c|}{ Mental health } \\
\hline & $(1)$ & (2) & (3) & (4) \\
\hline & Male & Female & Male & Female \\
\hline AQI & $\begin{array}{l}0.1381^{\star \star \star} \\
(0.0038)\end{array}$ & $\begin{array}{c}0.0439^{\star \star *} \\
(0.0022)\end{array}$ & $\begin{array}{c}-0.1678^{\star \star \star} \\
(0.0057)\end{array}$ & $\begin{array}{c}-0.1511^{\star \star \star} \\
(0.0029)\end{array}$ \\
\hline Education & $\begin{array}{r}0.0063 \\
(0.0128)\end{array}$ & $\begin{array}{c}0.0023 \\
(0.0146)\end{array}$ & $\begin{array}{l}0.3802^{\star \star \star} \\
(0.0228)\end{array}$ & $\begin{array}{c}0.5166^{\star \star \star} \\
(0.0168)\end{array}$ \\
\hline Age & $\begin{array}{l}0.0099^{\star \star \star} \\
(0.0026)\end{array}$ & $\begin{array}{c}0.0146^{\star \star \star} \\
(0.0022)\end{array}$ & $\begin{array}{c}-0.0328^{\star \star \star} \\
(0.0038)\end{array}$ & $\begin{array}{c}-0.0329^{\star \star \star} \\
(0.0040)\end{array}$ \\
\hline Gender & $\begin{array}{r}0.0000 \\
(0.0000)\end{array}$ & $\begin{array}{c}0.0000 \\
(0.0000)\end{array}$ & $\begin{array}{r}0.0000 \\
(0.0000)\end{array}$ & $\begin{array}{c}0.0000 \\
(0.0000)\end{array}$ \\
\hline Married & $\begin{array}{r}0.0148 \\
(0.0531)\end{array}$ & $\begin{array}{c}0.0069 \\
(0.0529)\end{array}$ & $\begin{array}{l}0.3983^{\star \star \star} \\
(0.1059)\end{array}$ & $\begin{array}{c}0.4225^{\star \star \star} \\
(0.0745)\end{array}$ \\
\hline Lwchi & $\begin{array}{l}-0.0151 \\
(0.0403)\end{array}$ & $\begin{array}{l}-0.0281 \\
(0.0440)\end{array}$ & $\begin{array}{l}-0.0235 \\
(0.0630)\end{array}$ & $\begin{array}{c}0.1015 \\
(0.0717)\end{array}$ \\
\hline Sleep & $\begin{array}{l}0.1368^{\star \star \star} \\
(0.0205)\end{array}$ & $\begin{array}{c}0.1221^{\star \star \star} \\
(0.0195)\end{array}$ & $\begin{array}{c}-0.4992^{\star \star \star} \\
(0.0280)\end{array}$ & $\begin{array}{c}-0.5315^{\text {ᄎ**}} \\
(0.0260)\end{array}$ \\
\hline Medins & $\begin{array}{r}0.0596 \\
(0.1401)\end{array}$ & $\begin{array}{l}0.3070^{\star \star} \\
(0.1198)\end{array}$ & $\begin{array}{l}0.4794^{*} \\
(0.2449)\end{array}$ & $\begin{array}{l}0.5666^{\star \star} \\
(0.2307)\end{array}$ \\
\hline sewpro & $\begin{array}{c}-0.0919^{\star \star \star} \\
(0.0030)\end{array}$ & $\begin{array}{c}-0.0096^{\star \star \star} \\
(0.0019)\end{array}$ & $\begin{array}{l}0.1382^{\star \star \star} \\
(0.0036)\end{array}$ & $\begin{array}{c}0.0932^{\star \star \star} \\
(0.0030)\end{array}$ \\
\hline gartre & $\begin{array}{l}0.1594^{\star \star \star} \\
(0.0048)\end{array}$ & $\begin{array}{c}0.0509^{\star \star \star} \\
(0.0022)\end{array}$ & $\begin{array}{c}-0.1856^{\star \star \star} \\
(0.0067)\end{array}$ & $\begin{array}{c}-0.1575^{\star \star \star} \\
(0.0026)\end{array}$ \\
\hline bedper & $\begin{array}{l}0.0014^{\star \star \star} \\
(0.0002)\end{array}$ & $\begin{array}{c}0.0016^{\star \star \star} \\
(0.0002)\end{array}$ & $\begin{array}{c}-0.0224^{\star \star *} \\
(0.0005)\end{array}$ & $\begin{array}{c}-0.0110^{\star \star \star} \\
(0.0007)\end{array}$ \\
\hline Indensity & $\begin{array}{l}0.5508^{\star \star \star} \\
(0.0119)\end{array}$ & $\begin{array}{l}0.0459^{\star \star} \\
(0.0197)\end{array}$ & $\begin{array}{l}0.1796^{\star \star \star} \\
(0.0231)\end{array}$ & $\begin{array}{c}0.0960^{\star \star \star} \\
(0.0279)\end{array}$ \\
\hline Inpergdp & $\begin{array}{l}0.9754^{\star \star \star} \\
(0.0299)\end{array}$ & $\begin{array}{c}-0.0583^{\star \star \star} \\
(0.0092)\end{array}$ & $\begin{array}{c}-0.6070^{\star \star \star} \\
(0.0487)\end{array}$ & $\begin{array}{c}-0.4303^{\star \star \star} \\
(0.0196)\end{array}$ \\
\hline City fixed effects & Yes & Yes & Yes & Yes \\
\hline Year fixed effects & Yes & Yes & Yes & Yes \\
\hline Constant & $\begin{array}{c}-32.0890^{\star \star \star} \\
(0.6985)\end{array}$ & $\begin{array}{c}-8.4218^{\star \star \star} \\
(0.3669)\end{array}$ & $\begin{array}{c}25.2380^{\star \star \star} \\
(1.1593)\end{array}$ & $\begin{array}{c}22.7466^{\star \star \star} \\
(0.7032)\end{array}$ \\
\hline Observations & 3629 & 3995 & 3064 & 3034 \\
\hline Adjusted $R^{2}$ & 0.029 & 0.044 & 0.353 & 0.499 \\
\hline Chi2 & $465.88^{\star \star \star}$ & & $8.45^{\star \star \star}$ & \\
\hline
\end{tabular}

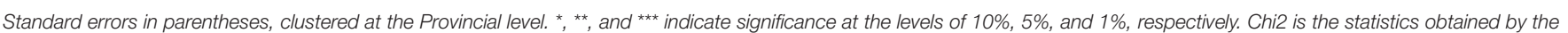
difference test between groups for AQI, and Chi2_p is the corresponding P-value.

and lifestyles. Thus, we test the heterogeneous effects of air pollution on physical and mental health between men and women, and present the results in Table 7. In both male and female samples in columns (1)-(4), the direction of the effects of air pollution on physical health and mental health is similar, but the degree of the effects differs. Moreover, male samples have larger coefficients of AQI than female samples, and the AQI coefficient difference tests for male and female samples are statistically significant. Therefore, we can conclude that air pollution adversely affects population health of males more than females. A similar result is obtained by Gu et al. (64).

Why does air pollution affect men's health more than women? On the one hand, Males and females may be affected by air pollution differently because males spend more time outdoors than females, so they are exposed to air pollution for a longer period of time. On the other hand, there are two major tissues of the human central nervous system: gray matter and white matter. Mathematical ability is often reflected in gray matter, while language expression ability is reflected in white matter (72). Furthermore, there are more activated gray cells in the brains of men than females in the intelligence test (73). In this case, those exposed to air pollution would also have diminished mathematical ability, but more pronounced for males than females. In this case, it makes sense that air pollution has a greater impact on mental health in men since mental cognition is primarily based on mathematical ability.

\section{Further Analysis: Hospital Costs of Air Pollution}

Air pollution adversely affects physical and mental health, as demonstrated above. The question that remains then is how 
TABLE 8 | The effects of air pollution on hospital costs.

\begin{tabular}{|c|c|c|c|}
\hline & $\begin{array}{c}\text { (1) } \\
\text { InHospcost }\end{array}$ & $\begin{array}{c}\text { (2) } \\
\text { InHospcost }\end{array}$ & $\begin{array}{c}\text { (3) } \\
\text { InHospcost }\end{array}$ \\
\hline AQI & $\begin{array}{l}0.1906^{\star \star *} \\
(0.0037)\end{array}$ & & \\
\hline PM2.5 & & $\begin{array}{c}0.1926^{\star \star \star} \\
(0.0037)\end{array}$ & \\
\hline PM10 & & & $\begin{array}{c}0.3322^{\star \star \star} \\
(0.0064)\end{array}$ \\
\hline Education & $\begin{array}{r}0.0065 \\
(0.0153)\end{array}$ & $\begin{array}{c}0.0065 \\
(0.0153)\end{array}$ & $\begin{array}{r}0.0065 \\
(0.0153)\end{array}$ \\
\hline Age & $\begin{array}{l}0.0315^{\star \star \star} \\
(0.0041)\end{array}$ & $\begin{array}{c}0.0315^{\star \star \star} \\
(0.0041)\end{array}$ & $\begin{array}{l}0.0315^{\star \star \star} \\
(0.0041)\end{array}$ \\
\hline Gender & $\begin{array}{c}0.0564 \\
(0.0575)\end{array}$ & $\begin{array}{c}0.0564 \\
(0.0575)\end{array}$ & $\begin{array}{r}0.0564 \\
(0.0575)\end{array}$ \\
\hline Married & $\begin{array}{l}-0.0144 \\
(0.0862)\end{array}$ & $\begin{array}{c}-0.0144 \\
(0.0862)\end{array}$ & $\begin{array}{l}-0.0144 \\
(0.0862)\end{array}$ \\
\hline Lwchi & $\begin{array}{r}0.0433 \\
(0.0433)\end{array}$ & $\begin{array}{c}0.0433 \\
(0.0433)\end{array}$ & $\begin{array}{c}0.0433 \\
(0.0433)\end{array}$ \\
\hline Sleep & $\begin{array}{l}0.1231^{\star \star \star} \\
(0.0151)\end{array}$ & $\begin{array}{c}0.1231^{\star * *} \\
(0.0151)\end{array}$ & $\begin{array}{l}0.1231^{\star * *} \\
(0.0151)\end{array}$ \\
\hline Medins & $\begin{array}{l}0.3948^{\star \star \star} \\
(0.1271)\end{array}$ & $\begin{array}{c}0.3948^{\star \star \star} \\
(0.1271)\end{array}$ & $\begin{array}{l}0.3948^{\star \star \star} \\
(0.1271)\end{array}$ \\
\hline sewpro & $\begin{array}{c}-0.1540^{\star \star \star} \\
(0.0035)\end{array}$ & $\begin{array}{c}-0.0893^{\star \star \star} \\
(0.0023)\end{array}$ & $\begin{array}{c}-0.4590^{\star \star \star} \\
(0.0092)\end{array}$ \\
\hline gartre & $\begin{array}{l}0.2547^{\star \star *} \\
(0.0043)\end{array}$ & $\begin{array}{c}0.2124^{\star \star \star} \\
(0.0036)\end{array}$ & $\begin{array}{l}0.5562^{\star \star \star} \\
(0.0101)\end{array}$ \\
\hline bedper & $\begin{array}{l}0.0181^{\star \star \star} \\
(0.0003)\end{array}$ & $\begin{array}{c}-0.0363^{\star \star \star} \\
(0.0010)\end{array}$ & $\begin{array}{l}0.1449^{\star \star \star} \\
(0.0026)\end{array}$ \\
\hline Indensity & $\begin{array}{l}0.2415^{\star \star \star} \\
(0.0196)\end{array}$ & $\begin{array}{c}-0.0953^{\star \star \star} \\
(0.0196)\end{array}$ & $\begin{array}{l}1.9487^{\star * \star} \\
(0.0409)\end{array}$ \\
\hline Inpergdp & $\begin{array}{l}0.9079^{\star \star \star} \\
(0.0250)\end{array}$ & $\begin{array}{c}1.5892^{\star \star *} \\
(0.0376)\end{array}$ & $\begin{array}{l}0.8190^{\star \star \star} \\
(0.0234)\end{array}$ \\
\hline City fixed effects & Yes & Yes & Yes \\
\hline Year fixed effects & Yes & Yes & Yes \\
\hline Constant & $\begin{array}{c}-38.3107^{\star \star *} \\
(0.6816)\end{array}$ & $\begin{array}{c}-37.6067^{\star \star \star} \\
(0.6698)\end{array}$ & $\begin{array}{c}-68.6556^{\star \star \star} \\
(1.2243)\end{array}$ \\
\hline Observations & 6770 & 6770 & 6770 \\
\hline Adjusted $R^{2}$ & 0.042 & 0.042 & 0.042 \\
\hline
\end{tabular}

Standard errors in parentheses, clustered at the Provincial level. * ${ }^{* *}$, and ${ }^{* * *}$ indicate significance at the levels of 10, 5, and 1\%, respectively.

much are hospital costs caused by air pollution. Identifying the answer to this question is central to evaluating air pollution control policies' welfare effects. As show in Table 8, air pollution, represented by AQI, PM2.5, and PM10, can significantly improve the hospitalization costs of middle-aged and elderly people. That is, air pollution increases the medical costs of middle-aged and elderly people. This conclusion is consistent with the finding obtained by Zeng et al. (74) using provincial-level data. In terms of AQI in columns (1), hospitalization costs increase by about $19.06 \%$ for every 1 unit increase in AQI. In terms of PM2.5 in columns (2), for every $1 \mu \mathrm{g} / \mathrm{m}^{3}$ increase in PM2.5, hospitalization costs will increase by about $19.26 \%$. In terms of PM10 in columns (3), for every $1 \mu \mathrm{g} / \mathrm{m}^{3}$ increase in PM10, hospitalization costs will also increase by about $33.22 \%$. As a result, it can be concluded that air pollution will result in huge hospital expenditures.
This estimation result is quite different from the study of Liao et al. (4). Their study showed that hospitalization costs increase by about $2 \%$ for every $10 \mu \mathrm{g} / \mathrm{m}^{3}$ increase in PM2.5 concentration. This difference can be attributed to the fact that Liao et al. used data from China Family Panel Studies (CFPS), which includes all family members in the sample households. The CHARL used in this study mainly targets the middle-aged and elderly people in the sample households, among which about $36 \%$ of the population are over 65 years old. Elderly people have poor physical fitness, are sensitive to environmental changes, and are more susceptible to air pollution, which can lead to diseases related to aging (75), thereby spend more on hospitalization costs than young people (9).

\section{CONCLUSIONS AND IMPLICATIONS}

Based on the CHARLS data in 2015 and 2018, this study applies a panel fixed effects model to empirically test the population health effects of air pollution among middle-aged and elderly residents. First, we divide population health into physical health and mental health, and then test the health effects of air pollution on them. The results indicate that air pollution is harmful to both physical and mental health. Each 10 increase of AQI will cause the physical health score to drop by 0.72 , and each 1 increase of AQI will contribute a decrease of about 0.15 to mental health, which is equal to $23.70 \%$ of the sample mean.

Second, heterogeneity tests are performed on the population health effects of air pollution based on both health categories and gender, respectively. In terms of physical health, air pollution can increase acute shock and chronic shock, but it has a greater impact on chronic shock than acute shock. In terms of mental health, air pollution can impair memory and cognitive abilities and exacerbate depression. In addition, the effects of air pollution on physical and mental health differ significantly between males and females. Air pollution has a more detrimental effect on men than on women.

Third, the hospital costs of air pollution are examined in this study. The estimation results using AQI, PM2.5, and PM10 are all consistent with the fact that air pollution will lead to a huge increase in hospitalization costs.

Important policy implications can be drawn from this study as well. To begin with, prior to formulating public health policies, it is important to take into account both physical and mental health effects of air pollution. The government can set up health consultation centers for middle-aged and elderly people in the community so that they can identify the physical and mental risks that middle-aged and elderly people face. Moreover, it is also important to develop differentiated environmental public health policies based on the differing effects of air pollution on acute shock, chronic shock, memory ability, cognitive ability, and depression. The government should determine the level of financial investment according to the level of adverse health effects caused by air pollution. Furthermore, government health departments should develop 
guidelines that differentiate the effects of air pollution on males and females.

However, there are still some shortcomings in this study. In addition to directly harming the health of middle-aged and elderly people by causing some diseases, air pollution may indirectly harm them by aggravating diseases they already have. It is important to differentiate between direct and indirect effects in order to better manage pollution-related adverse health effects. Nonetheless, this study is unable to test the direct and indirect effects due to non-availability of data. With the possible acquisition of tracking data for individual disease monitoring, it may be possible in the future to make a detailed analysis of the direct and indirect effects of air pollution on health. In addition, due to the lack of data, this study has not been able to discuss related issues caused by COVID-19 pandemic. COVID-19 pandemic may result in a large number of people losing their jobs $(76,77)$, thereby lowering their living standards, which may exacerbate air pollution's adverse effects on health. In comparison with studies on air pollution's impact on health, there are relatively few studies on the factors that impact air pollution, such as

\section{REFERENCES}

1. Murray CJL, Aravkin AY, Zheng P, Abbafati C, Abbas MK, Abbasi-Kangevari $\mathrm{M}$, et al. Global burden of 87 risk factors in 204 countries and territories, 19902019: a systematic analysis for the Global Burden of Disease Study 2019. The Lancet. (2020) 6:1223-49. doi: 10.1016/S0140-6736(20)30752-2

2. Khan $\mathrm{K}$, Su C-W. Urbanization and carbon emissions: a panel threshold analysis. Environ Sci Pollut R. (2021) 28:2607381. doi: 10.1007/s11356-021-12443-6

3. Ministry of Ecology and Environment. Bulletin of STATE of China's Ecological Environment. (2020). Available online at: http://www.mee.gov.cn/hjzl/sthjzk/ zghjzkgb/202105/P020210526572756184785.pdf (accessed on May 26, 2021)

4. Liao L, Du M, Chen Z. Air pollution, health care use and medical costs: evidence from China. Energ Econ. (2021) 95:105132. doi: 10.1016/j.eneco.2021.105132

5. Anderson HR. Air pollution and mortality: a history. Atmos Environ. (2009) 43:142-52. doi: 10.1016/j.atmosenv.2008.09.026

6. Wei Y, Wang Y, Wu X, Di Q, Shi L, Koutrakis P, et al. Causal effects of air pollution on mortality rate in massachusetts. Am J Epidemiol. (2020) 189:1316-23. doi: 10.1093/aje/kwaa098

7. Sun T-T, Tao R, Su C-W, Umar M. How do economic fluctuations affect the mortality of infectious diseases? Front Public Health. (2021) 9:411. doi: 10.3389/fpubh.2021.678213

8. Geng G, Zheng Y, Zhang Q, Xue T, Zhao H, Tong D, et al. Drivers of PM2.5 air pollution deaths in China 2002-2017. Nat Geosci. (2021) 14:64550. doi: 10.1038/s41561-021-00792-3

9. Manisalidis I, Stavropoulou E, Stavropoulos A, Bezirtzoglou E. Environmental and health impacts of air pollution: a review. Front Public Health. (2020) 8:14. doi: 10.3389/fpubh.2020.00014

10. Guo $\mathrm{H}$, Chang $\mathrm{Z}, \mathrm{Wu} \mathrm{J}, \mathrm{Li}$ W. Air pollution and lung cancer incidence in China: who are faced with a greater effect? Environ Int. (2019) 132:105077. doi: 10.1016/j.envint.2019.105077

11. Yi F, Ye H, Wu X, Zhang YY, Jiang F. Self-aggravation effect of air pollution: evidence from residential electricity consumption in China. Energ Econ. (2020) 86:104684. doi: 10.1016/j.eneco.2020.104684

12. Kulhánová I, Morelli X, Le Tertre A, Loomis D, Charbotel B, Medina S, et al. The fraction of lung cancer incidence attributable to fine particulate air pollution in France: impact of spatial resolution of air pollution models. Environ Int. (2018) 121:1079-86. doi: 10.1016/j.envint.2018.09.055 environmental innovation, environmental taxes (78), and other factors impact pollution levels. We will further expand on the basis of this study and explore how to reduce air pollution in the future.

\section{DATA AVAILABILITY STATEMENT}

The raw data supporting the conclusions of this article will be made available by the authors, without undue reservation.

\section{AUTHOR CONTRIBUTIONS}

W-TS: conceptualization, analyzing, and writing-original draft. XY: writing and reviewing. S-BZ: writing, editing, and supervising. H-RG: data preparation and software. All authors contributed to the article and approved the submitted version.

\section{FUNDING}

This research was partly supported by the Soft Science Research Plan Project of Zhejiang Province (grant number 2021C35087).
13. Franchini M, Mannucci PM. Air pollution and cardiovascular disease. Thromb Res. (2012) 129:230-4. doi: 10.1016/j.thromres.2011.10.030

14. Mills NL, Donaldson K, Hadoke PW, Boon NA, MacNee W, Cassee FR, et al. Adverse cardiovascular effects of air pollution. Nat Clin Pract Card. (2009) 6:36-44. doi: 10.1038/ncpcardio 1399

15. Brunekreef B, Holgate ST. Air pollution and health. The Lancet. (2002) 360:1233-42. doi: 10.1016/S0140-6736(02)11274-8

16. Katoto PDMC, Byamungu L, Brand AS, Mokaya J, Strijdom H, Goswami $\mathrm{N}$, et al. Ambient air pollution and health in Sub-Saharan Africa: current evidence, perspectives and a call to action. Environ Res. (2019) 173:17488. doi: $10.1016 /$ j.envres.2019.03.029

17. Phosri A, Ueda K, Phung VLH, Tawatsupa B, Honda A, Takano H. Effects of ambient air pollution on daily hospital admissions for respiratory and cardiovascular diseases in Bangkok, Thailand. Sci Total Environ. (2019) 651:1144-53. doi: 10.1016/j.scitotenv.2018.09.183

18. Kurata M, Takahashi K, Hibiki A. Gender differences in associations of household and ambient air pollution with child health: evidence from household and satellite-based data in Bangladesh. World Dev. (2020) 128:104779. doi: 10.1016/j.worlddev.2019.104779

19. Peled R. Air pollution exposure: who is at high risk? Atmos Environ. (2011) 45:1781-5. doi: 10.1016/j.atmosenv.2011.01.001

20. Chen S, Guo C, Huang X. Air pollution, student health, and school absences: evidence from China. J Environ Econ Manag. (2018) 92:46597. doi: 10.1016/j.jeem.2018.10.002

21. Gouveia N, Junger WL, Romieu I, Cifuentes LA, de Leon AP, Vera J, et al. Effects of air pollution on infant and children respiratory mortality in four large Latin-American cities. Environ Pollut. (2018) 232:38591. doi: 10.1016/j.envpol.2017.08.125

22. Chen Z, Cui L, Cui X, Li X, Yu K, Yue K, et al. The association between high ambient air pollution exposure and respiratory health of young children: a cross sectional study in Jinan, China. Sci Total Environ. (2019) 656:7409. doi: 10.1016/j.scitotenv.2018.11.368

23. Tang $M$, Li D, Liew $Z$, Wei F, Wang J, Jin $M$, et al. The association of short-term effects of air pollution and sleep disorders among elderly residents in China. Sci Total Environ. (2020) 708:134846. doi: 10.1016/j.scitotenv.2019.134846

24. Honda T, Pun VC, Manjourides J, Suh H. Anemia prevalence and hemoglobin levels are associated with long-term exposure to air pollution in an older population. Environ Int. (2017) 101:125-32. doi: 10.1016/j.envint.2017.01.017 
25. Gu H, Yan W, Elahi E, Cao Y. Air pollution risks human mental health: an implication of two-stages least squares estimation of interaction effects. Environ Sci Pollut R. (2020) 27:2036-43. doi: 10.1007/s11356-019-06612-x

26. Wei F, Yu Z, Zhang X, Wu M, Wang J, Shui L, et al. Longterm exposure to ambient air pollution and incidence of depression: a population-based cohort study in China. Sci Total Environ. (2021) 804:149986. doi: 10.1016/j.scitotenv.2021.149986

27. Li M, Ferreira S, Smith TA, Zhang X. Air pollution and noncognitive traits among Chinese adolescents. Health Econ. (2021) 30:478-88. doi: 10.1002/hec.4193

28. Chen S, Oliva P, Zhang P. Air Pollution and Mental Health: Evidence from China. (2018). Available online at: https://www.nber.org/system/files/ working_papers/w24686/w24686.pdf. doi: 10.3386/w24686

29. Jia Z, Wei Y, Li X, Yang L, Liu H, Guo C, et al. Exposure to ambient air particles increases the risk of mental disorder: findings from a natural experiment in Beijing. Int J Env Res Pub He. (2018) 15:160. doi: 10.3390/ijerph15010160

30. Sarkar C, Webster C, Gallacher J. Residential greenness and prevalence of major depressive disorders: a cross-sectional, observational, associational study of 94879 adult UK Biobank participants. Lancet Planet Health. (2018) 2:e16273. doi: 10.1016/S2542-5196(18)30051-2

31. Crouse DL, Pinault L, Christidis T, Lavigne E, Thomson EM, Villeneuve PJ. Residential greenness and indicators of stress and mental wellbeing in a Canadian national-level survey. Environ Res. (2021) 192:110267. doi: 10.1016/j.envres.2020.110267

32. Dadvand $P$, Nieuwenhuijsen MJ, Esnaola $M$, Forns J, Basagaña $\mathrm{X}$, Alvarez-Pedrerol $\mathrm{M}$, et al. Green spaces and cognitive development in primary schoolchildren. P Nat Acad Sci. (2015) 112:7937. doi: 10.1073/pnas.1503402112

33. Xue T, Zhu T, Zheng Y, Zhang Q. Declines in mental health associated with air pollution and temperature variability in China. Nat Commun. (2019) 10:2165. doi: 10.1038/s41467-019-11660-5

34. Fan X, Guo X, Ren Z, Li X, He M, Shi H, et al. The prevalence of depressive symptoms and associated factors in middle-aged and elderly Chinese people. J Affect Disorders. (2021) 293:222-8. doi: 10.1016/j.jad.2021.06.044

35. Ren T, Yu X, Yang W. Do cognitive and non-cognitive abilities mediate the relationship between air pollution exposure and mental health? PLoS ONE. (2019) 14:e0223353. doi: 10.1371/journal.pone.0223353

36. Qiu Y, Yang F-A, Lai W. The impact of indoor air pollution on health outcomes and cognitive abilities: empirical evidence from China. Popul Environ. (2019) 40:388-410. doi: 10.1007/s11111-019-00317-6

37. Wu Y, Ye Z. Fang Y. Spatial analysis of the effects of PM25 on hypertension among the middle-aged and elderly people in China. Int J Environ Heal R. (2021) 31:729-40. doi: 10.1080/09603123.2019.1682528

38. Bahadar H, Mostafalou S, Abdollahi M. Current understandings and perspectives on non-cancer health effects of benzene: a global concern. Toxicol Appl Pharm. (2014) 276:83-94. doi: 10.1016/j.taap.2014.02.012

39. Xing Y-F, Xu Y-H, Shi M-H. Lian Y-X. The impact of PM25 on the human respiratory system. J Thorac Dis. (2016) 8:E6974. doi: 10.3978/j.issn.2072-1439.2016.01.19

40. Sigaud S, Goldsmith C-AW, Zhou H, Yang Z, Fedulov A, Imrich A, et al. Air pollution particles diminish bacterial clearance in the primed lungs of mice. Toxicol Appl Pharm. (2007) 223:1-9. doi: 10.1016/j.taap.2007.04.014

41. Zhao C-N, Xu Z, Wu G-C, Mao Y-M, Liu L-N, Qian W, et al. Emerging role of air pollution in autoimmune diseases. Autoimmun Rev. (2019) 18:60714. doi: 10.1016/j.autrev.2018.12.010

42. Shukla A, Bunkar N, Kumar R, Bhargava A, Tiwari R, Chaudhury K, et al. Air pollution associated epigenetic modifications: transgenerational inheritance and underlying molecular mechanisms. Sci Total Environ. (2019) 656:76077. doi: 10.1016/j.scitotenv.2018.11.381

43. Chen Z-H, Wu Y-F, Wang P-L, Wu Y-P, Li Z-Y, Zhao Y, et al. Autophagy is essential for ultrafine particle-induced inflammation and mucus hyperproduction in airway epithelium. Autophagy. (2016) 12:297311. doi: 10.1080/15548627.2015.1124224

44. Guan W-J, Zheng X-Y, Chung KF, Zhong N-S. Impact of air pollution on the burden of chronic respiratory diseases in China: time for urgent action. Lancet. (2016) 388:1939-51. doi: 10.1016/S0140-6736(16)31597-5

45. Wolhuter K, Arora M, Kovacic JC. Air pollution and cardiovascular disease: can the Australian bushfires and global COVID-19 pandemic of 2020 convince us to change our ways? BioEssays. (2021) 43:2100046. doi: 10.1002/bies.202100046

46. Heyes A, Zhu M. Air pollution as a cause of sleeplessness: social media evidence from a panel of Chinese cities. J Environ Econ Manag. (2019) 98:102247. doi: 10.1016/j.jeem.2019.07.002

47. Wang Y, Yang Y, Zhao N, Liu C, Wang Q. The magnitude of the effect of air pollution on sunshine hours in China. J Geophys Res: Atmos. (2012) 117:1-9. doi: 10.1029/2011JD016753

48. Zhang C, Shen C, Yang Q, Wei S, Lv G, Sun C. An investigation on the attenuation effect of air pollution on regional solar radiation. Renew Energ. (2020) 161:570-8. doi: 10.1016/j.renene.2020.07.146

49. Grant WB, Strange RC, Garland CF. Sunshine is good medicine. The health benefits of ultraviolet-B induced vitamin D production. J Cosmet Dermatol. (2003) 2:86-98. doi: 10.1111/j.1473-2130.2004.00041.x

50. Neidell M. Information, avoidance behavior, and health: the effect of ozone on asthma hospitalizations. J Hum Resour. (2009) 44:45078. doi: $10.3368 /$ jhr. 44.2 .450

51. Graff Zivin J, Neidell M. The impact of pollution on worker productivity. Am Econo Rev. (2012) 102:3652-73. doi: 10.1257/aer.102.7.3652

52. Kim SY, Bang M, Wee JH, Min C, Yoo DM, Han S-M, et al. Short- and long-term exposure to air pollution and lack of sunlight are associated with an increased risk of depression: a nested case-control study using meteorological data and national sample cohort data. Sci Total Environ. (2021) 757:143960. doi: 10.1016/j.scitotenv.2020.143960

53. Zhou Y-M, Fan Y-N, Yao C-Y, Xu C, Liu X-L, Li X, et al. Association between short-term ambient air pollution and outpatient visits of anxiety: a hospital-based study in northwestern China. Environ Res. (2021) 197:111071. doi: 10.1016/j.envres.2021.111071

54. Moulton PV, Yang W. Air pollution, oxidative stress, and Alzheimer's Disease. J Environ Public Hea. (2012) 2012:472751. doi: 10.1155/2012/ 472751

55. Salim S, Chugh G, Asghar M. Chapter one-inflammation in anxiety. In: Donev R, editor. Advances in Protein Chemistry and Structural Biology. USA: Academic Press (2012). Vol. 88, p. 1-25. doi: 10.1016/B978-0-12-398314-5.00 001-5

56. Fleehart S, Fan VS, Nguyen HQ, Lee J, Kohen R, Herting JR, et al. Prevalence and correlates of suicide ideation in patients with COPD: a mixed methods study. Int J Chron Obstruct Pulmon Dis. (2014) 10:1321-9. doi: 10.2147/COPD .S65507

57. Kumar A, Nayar KR. COVID 19 and its mental health consequences. $J$ Ment Health. (2021) 30:1-2. doi: 10.1080/09638237.2020.17 57052

58. Feng W, Yuan H. Haze pollution and economic fluctuations: an empirical analysis of Chinese cities. Clean Environ Syst. (2021) 2:100010. doi: 10.1016/j.cesys.2021. 100010

59. Avdic D, de New SC, Kamhöfer DA. Economic downturns and mental health in Germany. Eur Econ Rev. (2021) 103915. doi: 10.1016/j.euroecorev.2021.103915

60. Zhao Y, John S, Xinxin C, Yafeng W, Jinquan G, Qinqin M, et al. China health and retirement longitudinal study wave 4 user's guide. National School of Development, Peking University (2020).

61. Liu L, Yang X, Liu H, Wang M, Welles S, Márquez S, et al. Spatialtemporal analysis of air pollution, climate change, and total mortality in 120 Cities of China, 2012-2013. Front Public Health. (2016) 4:143. doi: $10.3389 /$ fpubh.2016.00143

62. Zhang X-T, Liu X-H, Su C-W, Umar M. Does asymmetric persistence in convergence of the air quality index (AQI) exist in China? Environ Sci Pollut R. (2020) 27:36541-69. doi: 10.1007/s11356-020-09498-2

63. Su C-W, Wang K-H, Tao R, Lobont O-R. The asymmetric effect of air quality on cross-industries' stock returns: evidence from China. Environ Sci Pollut $R$. (2019) 26:31422-33. doi: 10.1007/s11356-019-06283-8

64. Gu H, Cao Y, Elahi E, Jha SK. Human health damages related to air pollution in China. Environ Sci Pollut R. (2019) 26:1311525. doi: 10.1007/s11356-019-04708-y

65. Hu K, Keenan K, Hale JM, Börger T. The association between city-level air pollution and frailty among the elderly population in China. Health Place. (2020) 64:102362. doi: 10.1016/j.healthplace.2020.102362 
66. Giaccherini M, Kopinska J, Palma A. When particulate matter strikes cities: social disparities and health costs of air pollution. J Health Econ. (2021) 78:102478. doi: 10.1016/j.jhealeco.2021.102478

67. Grossman M. On the concept of health capital and the demand for health. $J$ Polit Econ. (1972) 80:223-55. doi: 10.1086/259880

68. Bishop KC, Ketcham JD, Kuminoff NV. Hazed and Confused: The Effect of Air Pollution on Dementia. (2018). Available online at: https://www.nber.org/ system/files/working_papers/w24970/w24970.pdf. doi: 10.3386/w24970

69. Guo H, Chen M. Short-term effect of air pollution on asthma patient visits in Shanghai area and assessment of economic costs. Ecotox Environ Safe. (2018) 161:184-9. doi: 10.1016/j.ecoenv.2018.05.089

70. Cheng $\mathrm{Z}$, Li L, Liu J. Identifying the spatial effects and driving factors of urban PM2.5 pollution in China. Ecol Indic. (2017) 82:6175. doi: 10.1016/j.ecolind.2017.06.043

71. Yang X, Jiang L, Zhao W, Xiong Q, Zhao W. Yan X. Comparison of groundbased PM25 and PM10 concentrations in China, India, and the US. Int J Env Res Pub He. (2018) 15:1382. doi: 10.3390/ijerph15071382

72. Chen X, Zhang X, Zhang X. Smog in Our Brains: Gender Differences in the Impact of Exposure to Air Pollution on Cognitive Performance. (2017). Available online at: https://papers.ssrn.com/sol3/Data_Integrity_Notice.cfm? abid $=2940618$

73. Haier RJ, Jung RE, Yeo RA, Head K, Alkire MT. The neuroanatomy of general intelligence: sex matters. NeuroImage. (2005) 25:320327. doi: 10.1016/j.neuroimage.2004.11.019

74. Zeng M, Du J. Zhang W. Spatial-temporal effects of PM25 on health burden: evidence from China. Int J Env Res Pub He. (2019) 16:4695. doi: 10.3390/ijerph16234695

75. Evans MF, Smith VK. Do new health conditions support mortality-air pollution effects? J Environ Econ Manag. (2005) 50:496-518. doi: 10.1016/j.jeem.2005.04.002
76. Su C-W, Dai K, Ullah S, Andlib Z. COVID-19 pandemic and unemployment dynamics in European economies. Econ Res-Ekon Istră̌. 2021:1-13. doi: 10.1080/1331677X.2021. 1912627

77. Kong E, Prinz D. Disentangling policy effects using proxy data: which shutdown policies affected unemployment during the COVID-19 pandemic? J Public Econ. (2020) 189:104257. doi: 10.1016/j.jpubeco.2020. 104257

78. Tao R, Umar M, Naseer A, Razi U. The dynamic effect of ecoinnovation and environmental taxes on carbon neutrality target in emerging seven (E7) economies. J Environ Manage. (2021) 299:113525. doi: 10.1016/j.jenvman.2021.113525

Conflict of Interest: The authors declare that the research was conducted in the absence of any commercial or financial relationships that could be construed as a potential conflict of interest.

Publisher's Note: All claims expressed in this article are solely those of the authors and do not necessarily represent those of their affiliated organizations, or those of the publisher, the editors and the reviewers. Any product that may be evaluated in this article, or claim that may be made by its manufacturer, is not guaranteed or endorsed by the publisher.

Copyright (C) 2021 Shen, Yu, Zhong and Ge. This is an open-access article distributed under the terms of the Creative Commons Attribution License (CC BY). The use, distribution or reproduction in other forums is permitted, provided the original author(s) and the copyright owner(s) are credited and that the original publication in this journal is cited, in accordance with accepted academic practice. No use, distribution or reproduction is permitted which does not comply with these terms. 